\title{
PENGEMBANGAN LEMBAR KERJA SISWA ( LKS ) TEMA LINGKUNGAN SAHABAT KITA DI KELAS V ( LIMA ) SD MUHAMMADIYAH SANGATTA UTARA
}

\author{
Edi Wiyono, P.M Labulan, Muhammad Siddik \\ Universitas Mulawarman \\ wiyonoedi@,rocketmail.com
}

\begin{abstract}
The ability of teachers to create an atmosphere of learning that is conducive, effective and fun is one part of the professional competence of educators. The use of student worksheets in the teaching and learning process is one of the main choices for a teacher in arousing interest, motivation and stimulation of learning activities. The aim of this research is to produce a Worksheet product for the Themes of the Environment Around Us, the Human Themes and the 5th grade elementary school environment that are suitable for use in the learning process. The type of this research uses research and development methods or commonly referred to as research and development. This study uses the Borg and Gall development research procedure which consists of nine steps namely, gathering initial information, planning, developing initial product formats, initial trials, product revisions, field trials, product revisions, field trials, and final product revisions.The results showed that the Worksheet Product Students Environmental Themes Around Us Sub Themes Human and Environmental grade V SD used had very good eligibility. This finding is supported by field facts where the material expert validation obtained a score of $90.00 \%$, the media expert validation obtained $92.63 \%$, the linguist validation was $92.7 \%$, the student questionnaire assessment on the field test was $92.4 \%$, and the mean score was The average daily test for students increased by $12.50 \%$ from 71.96 to 84.46 .
\end{abstract}

Keywords: Development, Student Worksheets, Thematic Learning

\section{PENDAHULUAN}

Pembelajaran di Sekolah Dasar adalah proses yang sangat penting, di dalam proses pembelajaran terdapat usaha untuk membelajarkan peserta didik untuk lebih mengenal dirinya dan materi yang dipelajarinya. Menurut Sujarwo (2011:3) Pembelajaran adalah sebagai upaya membelajarkan peserta didik memahami diri dan lingkungnnya agar lebih bermakna. Pembelajaran yang dimaknai sebagai kegiatan memilih, menetapkan dan mengembangkan pengelolaan, pengorganisasian dan penyampaian pesan pembelajaran untuk mencapai yang ditetapkan. Guru merupakan orang yang sangat berpengaruh dalam kesuksesan pembelajaran, ketercapaian kompetensi, dan sikap yang diharapkan dari peserta didik. Guru dalam hal ini dituntut untuk selalu berusaha meningkatkan kualitas pembelajaran yang dilakukan terutama di dalam mempersiapkan atau mendesain pembelajaran maupun pemilihan media sebagai pengantar materi pembelajaran.
Pada kenyataannya pembelajaran yang mengandung materi tersebut belum menggunakan kegiatan pembelajaran yang melibatkan peserta didik baik dalam LKS maupum petunjuk guru secara langsung.

LKS sangat dibutuhkan dalam pembelajaran, LKS merupakan lembar-lembar kertas yang berisi materi-materi, rangkuman, dan petunjuk sebagai bahan ajar yang harus dikerjakan peserta didik, baik bersifat teori atau praktik, yang berpedoman kepada kompetensi dasar yang sudah ditentukan (Prastowo, 2013: 269).

Pembelajaran dengan menggunakan LKS memiliki banyak fungsi yaitu, meminimalkan peran pendidik namun mengoptimalkan peran peserta didik, memudahkan peserta didik memahami materi, untuk memudahkan peserta didik berinteraksi dengan materi, meningkatnya penguasaan dengan materi dengan tugastugasnya, melatih kemandirian belajar, dan memudahkan guru memberikan tugas kepada peserta didik. dapat menciptakan pembelajaran yang optimal terutama pada pembelajaran tematik. Proses kegiatan pembelajaran LKS 
tematik juga terdapat kegiatan yang kaya manfaat bagi peserta didik yang dapat meningkatkan kemampuan sikap, keterampilan, dan kognitif. Peserta didik dengan melakukan kegiatan yang ada di LKS dapat terlibat secara aktif untuk memahami materi pembelajaran. Selain melakukan kegiatan dapat juga peserta didik membaca materi dan ringkasan untuk mempermudah memahami materi pembelajaran.

Perencanaan pembelajaran guru yang baik dalam menyusun LKS dapat menghadirkan pembelajaran yang baik pula. LKS harus meliputi judul, petunjuk belajar, materi pokok, informasi pendukung, kegiatan, dan penilaian dalam bentuk soal. LKS yang digunakan peserta didik harus menyesuaikan dengan karakteristik peserta didik. Pada usia anak sekolah dasar lebih menyukai benda nyata atau bisa dalam bentuk gambar yang berwarna dibandingkan dengan text-book. Sesuai dengan tahap perkembangan peserta didik, menurut Piaget dalam Izzaty, dkk (2008: 104) masa kanak-kanak akhir berada dalam tahap operasional konkrit dalam berpikir (usia 7-12 tahun), konsep yang tidak jelas dan samar pada masa awal kanak-kanak sekarang lebih konkret. Peserta didik dalam memecahkan permasalahan yang actual menggunakan cara psikis yang bersifat konkrit.

Penggunaan LKS yang sesuai dengan perkembangan peserta didik juga akan memudahkan peserta didik memahami materi yang diajarkan dengan cepat. Penggunaan struktur penyusunan LKS yang baik akan memudahkan guru dan peserta didik dalam proses pembelajaran. Penyajian materi yang sesuai dengan perkembangan peserta didik akan mempermudah peserta didik memahami materi yang abstrak, sehigga ketercapaian kompetensi sesuai dengan yang diharapkan.

Pembelajaran yang ideal akan tercapai jika keseluruhan proses pembelajaran dan penunjang pembelajaran berlangsung dengan baik. Setelah observasi di dalam kelas V SD Muhammadiyah 2 Sangatta Utara untuk mengamati langsung kenyataan kegiatan pembelajaran masih ditemukan kegiatan yang belum sesuai dengan pembelajaran yang ideal. Penggunaan buku sebagai sumber belajar di dalam kelas tidak ada. Bahan ajar yang digunakan di dalam pembelajaran hanya satu yaitu LKS. LKS yang seharusnya dapat melibatkan peserta didik dalam proses pembelajaran juga tidak berfungsi dengan baik karena tidak memberikan pengalaman belajar peserta didik secara langsung.

Bahan ajar cetak yang berupa Lembar Kerja Siswa yang dominan digunakan oleh guru kelas V SD Muhammadiyah 2 Sangatta Utara, tidak menggambarkan LKS yang sesuai dengan perkembangan anak kelas V Sekolah Dasar. yang lebih menyukai dengan LKS bergambar. LKS tidak dilengkapi dengan kegiatan-kegiatan pembelajaran yang aktif dan mendorong peserta didik untuk berpikir kritis dan kreatif. Sedangkan berpikir sangat membantu dalam meningkatkan level koginitif siswa (Fitriadi, 2016).

Unsur-unsur LKS yang digunakan tidak tersusun dengan baik. LKS didominasi dengan latihan-latihan soal dan materi. Kegiatankegiatan yang harus dilakukan peserta didik tidak sesuai dengan kompetensi yang diharapkan. Guru kelas tidak memanfaatkan LKS dengan optimal karena hanya menggunakan soal-soal latihan dan tidak melakukan kegiatan yang seharusnya dilakukan peserta didik. Ketertarikan peserta didik pada tulisan bergambar peneliti temukan pada saat pengamatan diluar pembelajaran. Peserta didik berkunjung ke perpustakaan untuk memuaskan rasa keiigintahuannya membaca buku bergambar.

Berdasarkan uraian di atas, maka peneliti merasa perlu mengembangkan LKSdi kelas V SD Muhammadiyah 2 Sangatta Utara. LKS yang dikembangkan diharapkan dapat membantu mengatasi permasalahan yang ada. Pengembangan LKS dapat mempermudah peserta didik memahami materi dengan serangkaian kegiatan yang ada dalam LKS. Peserta didik akan merasa senang untuk belajar di dalam kelas dengan LKS yang menarik dan mudah dipahami. Kegiatan-kegiatan yang ada di dalam LKS dengan dilengkapi gambar yang akan memudahkan peserta didik untuk memahami materi. Hasil yang diharapkan adalah terciptanya pengembangan LKS di kelas V SD Muhammadiyah 2 Sangatta Utara pada Tema Lingkungan Sekitar Kita Sub Tema Manusia dan Lingkungan 


\section{KAJIAN TEORI}

\section{A. Hakekat Pendidikan}

Hakikat pendidikan adalah humanisasi. Suyitno (2009: 2) mengungkapkan bahwa," pendidikan yaitu upaya memanusiakan manusia". Dalam Undang-undang tentang Sistem Pendidikan Nasional No. 20 Tahun 2003 mengungkapkan bahwa

"Pendidikan merupakan usaha sadar dan terencana untuk mewujudkan proses belajar dan suasana belajar agar peserta didik secara aktif menumbuhkan diri sendiri untuk mempunyai keteguhan spiritual keagamaan, mengendalian diri, berkepribadian, kecerdasan, berakhlak mulia dan keterampilan yang diperlukan untuk dirinya, masyarakat, bangsa dan negara"

\section{B. Pendidikan Sekolah Dasar}

Dalam Pembukaan Undang-undang Dasar 1945, mengamanatkan bahwa pendidikan bertujuan untuk mencetak dan mencerdaskan kehidupan bangsa yang bertaqwa, berbudi pekerti yang luhur, cinta tanah air, kreatif ,terampil dan bangga terhadap bangsa dan negara, serta mampu menyelesaikan permasalahan di lingkungannya. Pengertian pendidikan di sekolah dasar mempunyai makna yang sama dengan pengertian yang terurai di atas, namun saja letak obyeknya atau siswanya saja yang membedakannya. Artinya, bahwa bahwa pendidikan di sekolah dasar penekanan fokus kepada peserta didik kelas 1 sampai kelas 6 yang ruang lingkup materinya atau kurikulumnya diatur tersendiri dalam GBPP (Garis-garis Besar Program Pengajaran). dengan tujuan yang sama seperti uraian pada Undangundang No. 20 tahun 2003 tentang sistem pendidikan.

\section{Kurikulum 2013}

Kurikulum adalah seperangkat rencana dan pengaturan mengenai tujuan, isi, dan bahan pelajaran serta cara yang digunakan sebagai pedoman penyelenggaraan kegiatan pembelajaran untuk mencapai tujuan pendidikan tertentu.

Kurikulum yang terbaru yaitu kurikulum 2013 yang mulai dilaksanakan pada tahun ajaran 2013-2014 pada sekolah yang ditunjuk pemerintah maupun sekolah yang siap melaksanakannya. Meskipun masih premature, namun ada beberapa hal yang dirasakan oleh banyak kalangan terutama yang langsung berhadapan dengan kurikulum itu sendiri.

\section{Pembelajaran tematik di Sekolah Dasar}

\section{Pengertian Pembelajaran Tematik}

Muslich (2011: 164) pembelajaran tematik adalah pembelajaran yang menggunakan mengaitkan beberapa mata pelajaran dalam tema sehingga dapat memberikan pengalaman belajar bermakna kepada peserta didik.

Prastowo (2013: 54) pembelajaran tematik merupakan pembelajaran terpadu yang pendekatan tematiknya melibatkan sebagian mata pelajaran untuk memberikan pengalaman bermakna kepada peserta didik. Berdasarkan pendapat para ahli diatas pembelajaran tematik merupakan pembelajaran yang dilakukan dengan mengambil materi yang digabungkan dari beberapa mata pelajaran menjadi satu tema. Materi atau kompetensi dasar yang diambil dari setiap mata pelajaran harus sesuai dengan tema pembelajaran.

2. Karakteristik Pembelajaran Tematik

a. Berpusat pada peserta didik (student centered).

b. Memberikan pengalaman langsung

c. Tidak begitu jelas pemisahan antar mata pelajaran

d. Menyajikan berbagai konsep dari beberapa mata pelajaran

e. Besifat fleksibel

f. Hasil pembelajaran sesuai dengan minat dan kebutuhan peserta didik

g. Menggunanakan prinsip belajar sambil bermain

\section{Tema pada Kelas V Sekolah Dasar Kurikulum Tingkat Satuan}

Pembelajaran di kelas V Sekolah Dasar terbagi menjadi delapan tema sebagai berikut.

a. Organ Gerak Hewan dan Manusia

b. Udara Bersih Bagi Kesehatan

c. Makanan Sehat

d. Sehat Itu Penting

e. Ekosistem

f. Panas dan Perpindahannya

g. Peristiwa dalam Kehidupan

h. Lingkungan Sahabat Kita

i. Benda-Benda di Sekitar Kita

E. Pengembangan LKS

1. Pengertian LKS 
LKS merupakan lembar-lembar kertas yang berisi materi, ringkasan, dan petunjuk pelaksanaan tugas pembelajaran yang harus dikerjakan peserta didik, baik bersifat teoritis dan/atau praktis, yang mengacu kepada kompetensi dasar yang harus dicapai peserta didik; dan penggunaanya tergantung bahan ajar lain (Prastowo, 2013: 269).

\section{Fungsi LKS}

a. Lebih mengaktifkan peran peserta didik dan meminimalkan peran pendidik sebagai bahan ajar.

b. Memudahkan peserta didik untuk memahami materi yang diberikan sebagai bahan ajar.

c. Sebagai bahan ajar yang ringkas dan kaya tugas untuk berlatih.

d. Memudahkan pelaksanaan pengajaran kepada peserta didik.

3. Manfaat LKS

a. Mempermudah guru untuk mengelola proses belajar, misalnya mengubah kondisi belajar dari suasana teacher center menjadi student center.

b. Membantu guru mengarahkan peserta didiknya untuk dapat menemukan konsepkonsep melalui aktivitasnya sendiri atau dalam kelompok kerja.

c. Mengembangkan keterampilan proses, mengembangkan sikap ilmiah serta membangkitkan minat peserta didik terhadap alam sekitarnya.

d. Memudahkan guru memantau keberhasilan peserta didik untuk mencapai sasaran belajar.

4. Tujuan Penggunaan LKS

a. Menyajikan bahan ajar yang membantu peserta didik untuk berinteraksi dengan materi yang diberikan dengan mudah

b. Menyajikan tugas-tugas yang menngkatkan penguasaan peserta didik terhadap materi yang diberikan.

c. Melatih belajar mandiri peserta didik.

d. Memudahkan pendidik dalam memberikan tugas kepada peserta didik.

\section{Komponen-komponen LKS}
a. Informasi
b. Pernyataan masalah
c. Pertanyaan dan perintah

d. Pertanyaan bersifat terbuka dan membimbing.

\section{Struktur LKS}

a. Judul

b. Kompetensi dasar yang akan dicapai

c. Waktu penyelesaian

d. Peralatan/bahan yang diperlukan untuk menyelesaikan tugas

e. Informasi singkat

f. Langkah kerja

g. Laporan

7. Syarat-Syarat LKS yang Baik
a. Syarat Didaktik
b. Syarat Kontruksi
c. Syarat teknis

8. Jenis-jenis LKS

a. LKS Penemuan

b. LKS Aplikatif-Integratif

c. LKS Penuntun

d. LKS Penguatan

e. LKS Praktikum

9. Langkah-langkah membuat LKS
a. Analisis Kurikulum
b. Menyusun Peta Kebutuhan LKS
c. Menentukan Judul-Judul LKS
d. Penulisan LKS

\section{Mengembangkan LKS yang Kaya Manfaat}

a. Menentukan Desain Pengembangan LKS ( Lembar Kerja Siswa )
1. Ukuran
2. Kepadatan Halaman
3. Penomoran
4. Kejelasan

b. Langkah-Langkah Pengembangan LKS

1. Menentukan tujuan pembelajaran yang akan di-breakdown dalam LKS

2. Pengumpulan materi

3. Menyusun unsur-unsur LKS ( Lembar Kerja Siswa )

4. Pemerikasaan dan penyempurnaan

\section{METODE PENGEMBANGAN}

Penelitian ini menggunakan prosedur pengembangan Borg and Gall. Dalam Punaji (2012: 228-230) menyatakan prosedur penelitian pengembangan mempunyai sepuluh langkah kegiatan pengembangan. Penelitian 
pengembangan ini dilakukan sampai tahap kesembilan saja, karena keterbatasan kemampuan dan waktu peneliti tahap yang kesepuluh atau tahap pembuatan produk masal tidak dilakukan

Berikut tahapan dari setiap tahap yang akan dilakukan pengembangan.

\section{Penelitian dan Pengumpulan \\ Informasi data Awal}

Penelitian dan pengumpulan informasi data awal dilakukan dengan kajian pustaka, pengamatan dan observasi kelas V Sekolah Dasar. Penelitian awal ini penting dilakukan untuk memperoleh informasi awal guna melakukan pengembangan. Kegiatan awal ini dilakukan dengan observasi langsung di dalam kelas V Sekolah Dasar untuk mendapatkan kondisi riil yang ada di dalam kelas. Observasi juga didukung dengan wawancara kepada guru dan kepala sekolah terkait dengan pembelajaran.

\section{Tahap Perencanaan}

Tahap perencanaan dalam pengembangan

LKS ( Lembar Kerja Siswa ).

a. Pembuatan desain awal LKS.

b. Menentukan tujuan pembelajaran

c. Mengumpulkan materi

d. Menyusun LKS sesuai dengan unsur-unsur

LKS yang baik.

e. Pemeriksaan dan penyempurnaan LKS

3. Pengembangan Format Produk Awal

Pada tahap ini peneliti mencetak produk LKS yang sudah dibuat kemudian dilakukan validasi ahli untuk menguji kelayakan produk. Validasi dilakukan dengan tiga dosen ahli materi, ahli media, dan ahli bahasa

\section{Uji Coba Awal}

Jumlah peserta didik yang diambil pada uji coba awal menurut pendapat Sadiman, dkk (2006: 183) menyatakan bahwa pada tahap ini dibutuhkan dua peserta didik atau lebih yang dapat mewakili populasi target dari penggunakan LKS yang dibuat. Peserta didik yang diuji coba tersebut mempunyai kemampuan umumnya dibawah rata-rata, sedang, dan diatas rata-rata.

\section{Revisi Produk}

Revisi produk ini dilakukan berdasarkan jawaban dari tahap uji coba awal.

\section{Uji Coba Lapangan}

Menurut Sadiman, dkk (2006: 184) pada tahap uji lapangan kecil dapat diujicobakan kepada 10 sampai 20 peserta didik yang dapat mewakili target. Peserta didik yang dipilih hendaknya mencerminkan karakteristik populasi. Sampel tersebut terdiri dari peserta didik yang kurang pandai, sedang, dan pandai, laki-laki dan perempuan; berbagai usia dan latar belakang.

\section{Revisi Produk}

Revisi produk ini dilakukan berdasarkan jawaban dari tahap uji coba lapangan.

\section{Uji Lapangan}

Menurut Sadiman, dkk (2006: 185) bahwa tahap evaluasi lapangan membutuhkan tiga puluh peserta didik dengan karakteristik (tingkat kepandaian, kelas, latar belakang, jenis kelamin, usia, dan lain-lain) sesuai dengan karakteristik sasaran.

\section{Revisi Produk Akhir}

Revisi produk akhir dilakukan setelah melakukan uji lapangan.

\section{A. Tempat dan Subyek Pengembangan}

Penelitian pengembangan LKS ini dilaksanakan di SD Muhammadiyah Sangatta Utara yang beralamat di Jalan Teluk Rawa RT.16 Desa Sangatta Utara, Kecamatan Sangatta Utara Kabupaten Kutai Timur, Provinsi Kalimantan Timur.

\section{B. Uji Coba Produk Pengembangan}

1. Validasi Ahli
a. Validasi Ahli Materi
b. Validasi Ahli Media
c. Validasi Ahli Bahasa

2. Uji Coba Produk

3. Jenis Data

Jenis data yang digunakan dalam penelitian ini berupa data kuantitatif dan data kualitatif. Penilaian diambil dari skor angket oleh ahli media, ahli materi, subjek uji coba. Data kualitatif adalah data mengenai pengembangan LKSyang berupa saran, kritik, masukan dari ahli. 4. Teknik dan Instrumen Pengumpulan Data

a. penilaian ahli, kuesioner atau angket dan tes yaitu :

1. Penilaian ahli

2. Kuesioner

3. Tes

b. Analisis data

Data dari angket merupakan data kualitatif yang dikuantitatifkan dengan menggunakan skala likeart . 
Untuk menentukan persentase tersebut dapat menggunakan rumus sebagai berikut :

$$
P=\frac{\sum x}{\Sigma x_{1}} x 100 \%
$$

Keterangan : $\mathrm{P}$ adalah prosentase kelayakan

$\sum x$ : adalah total skor jawaban validator (nilai nyata)

$\sum x_{1}$ : adalah jumlah total skor jawaban tertinggi (nilai harapan)

Kualifikasi tingkat kelayakan berdasarkan persentase

\begin{tabular}{|l|l|}
\hline Persentase (\%) & $\begin{array}{l}\text { Tingkat } \\
\text { Tercapainya }\end{array}$ \\
\hline $80-100$ & Sangat Baik \\
\hline $60-79$ & Baik \\
\hline $40-59$ & Cukup \\
\hline $0-39$ & Kurang Baik \\
\hline
\end{tabular}

\section{HASIL PENELITIAN DAN PEMBAHASAN}

Desain produk dari hasil pengembangan di desain sebagai bahan ajar berupa LKS diuji kevalitannya oleh ahli materi, media, dan bahasa.

Validasi pada ahli materi berlangsung dua tahap, pada tahap I memperoleh prosentase $85,71 \%$ yang masuk pada kriteria "sangat baik". Namun ada beberapa materi LKS yang perlu perbaikan. Setelah melakukan perbaikan, pada tahap II dengan memperoleh prosentase 90,00 \% yang masuk pada kriteria "sangat baik". Pada tahap II validasi materi sudah tidak ada revisi karena LKS sudah layak diujicobakan tanpa perbaikan.

Validasi media dilakukan berlangsung 2 tahap , pada tahap I validasi media memperoleh prosentase $86,32 \%$ yang masuk pada kriteria "sangat baik", namun perlu perbaikan . Pada tahap II yang memperoleh prosentase 92,63\% masuk pada kriteria "sangat baik". Dengan komentar dosen ahli media LKS sudah layak diujicobakan tanpa perbaikan.

Validasi ahli bahasa dilakukan berlangsung 2 tahap, pada tahap I validasi media memperoleh prosentase $86,32 \%$ yang masuk pada kriteria "sangat baik", namun perlu perbaikan. Pada tahap II yang memperoleh prosentase $92,63 \%$ masuk pada kriteria "sangat baik". Dengan komentar dosen ahli media LKS sudah layak diujicobakan tanpa perbaikan.

LKS dianggap layak dari segi materi, media, dan bahasa dilanjutkan pada tahap selanjutnya . Pada uji awal mendapat prosentase 94,17\% yang masuk kriteria "sangat baik". Tahap uji coba lapangan memperoleh prosentase 92,8 \% yang masuk pada kriteria "sangat baik". Tahap uji lapangan memperoleh prosentase 92,4 \% yang masuk kriteria "sangat baik",dan hasil nilai ulangan harian meningkat $12,94 \%$ dari 71,96 menjadi 84,46 . Berdasarkan hasil uji lapangan dan nilai ulangan harian tersebut LKS dinyatakan baik dan layak digunakan peserta didik kelas V Sekolah Dasar karena sudah mencapai kriteria "Sangat Baik" dan nilai ulangan harian meningkat .

\section{KESIMPULAN}

Kesimpulan yang dapat diambil dari penelitian pengembangan ini adalah :

1. Penelitian ini menggunakan prosedur penelitian pengembangan Borg and Gall yang terdiri sembilan langkah yaitu : 1) pengumpulan informasi awal, 2) perencanaan, 3) pengembangan format prosuk awal, 4) uji coba awal, 5) revisi prosuk, 6) uji coba lapangan, 7) revisi prosuk, 8) uji lapangan, 9) revisi prosuk akhir.

2. Hasil validasi produk dilakukan oleh tiga ahli materi, media, dan bahasa yang masing masing dua tahap. Penilaian ahli materi pada tahap pertama memperoleh skor prosentase $85,71 \%$ dan tahap ke dua $90 \%$. Penilaian ahli media pada tahap pertama memperoleh skor prosentase $86,32 \%$ dan tahap kedua 92,63\%. Penilaian ahli bahasa pada tahap pertama memperoleh skor $90,9 \%$ dan tahap 2 memperoleh skor $92,7 \%$. Sehingga validasi ahli materi, ahli media, dan ahli bahasa memperoleh penilaian dengan kriteria sangat baik.

3. Jawaban atau respon dari peserta didik dilakukan dengan tiga tahap yaitu, uji coba awal, uji coba lapangan, dan uji lapangan . pada uji coba awal mendapat jawaban atau respon dengan nilai prosentasi 94,17\% 
masuk kriteria " sangat baik ". Pada uji coba lapangan mendapat jawaban atau respon dengan nilai prosentasi $92,8 \%$ masuk kriteria " sangat baik ".Pada uji lapangan mendapat jawaban atau respon dengan nilai prosentasi 92,4\% masuk kriteria “ sangat baik ".Dan nilai rata-rata ulangan harian meningkat $12,50 \%$ dari nilai rata - rata 71,96 menjadi 84,46

4. Pada penelitian pengembangan ini menghasilkan produk LKS dengan Judul “ Pengembangan Lembar Kerja Siswa ( LKS ) Tema Lingkungan Sahabat Kita , Sub Tema Manusia dan Lingkungan.

\section{DAFTAR PUSTAKA}

Amri, Sofan. 2013. Pengembangan dan Model Pembelajaran dalam Kurikulum 2013. Prestasi Pustaka, Surabaya

Bock, D. B., Yager, S.E. (2005). Using the Data Modeling Worksheet to Improve Novice Data Modeler Performance.Educational Database. Vol. 16, 3.

Choo, S. S. Y., Rotgans, J. I., Yew, E. H. J., Schmidt, H. G. (2011). Effect of worksheet scaffolds on student learning in problem-based learning.Health Sciences Education, 520, 517-528.

Darmodjo, H., \& Kaligis. (1992). Pendidikan IP A II. Jakarta: Depdikbud.

Daryanto \& Dwicahyono, A. (2014). Pengembangan Perangkat Pembelajara Yogyakarta: Cava Media.

Depdiknas. (2008). Panduan Pengembangan Bahan Ajar. Jakarta: Depdiknas.

Fitriadi, A. (2016). The Correlation between Critical Thinking Skills and Critical Thinking Dispositions of the Fifth Semester Student of English Department in Academic Years 2015/2016. Konferensi Antarabangsa Islam Borneo Ke-9 (KAIB $I X), 9(25), 250$.

Hakim, M. A. (2014). Pengembangan Lembar Kerja Peserta didik (LKS) dengan Pendekatan Contextual
Teaching and Learning Materi Pokok Himpunan untuk Kelas VII SMP/MTs. Skripsi. Dipublikasikan. Universitas Islam Negeri Sunan Kalijaga.

Hung, P.-H., Lin, Y.-F., Hwang, G.-J.

(2010). Formative Assessment

Design for PDA Integrated Ecology

Observation. Educational

Technology\& Society, 13 (3), 33-42.

Izzaty, R. E., Suardiman, S. P., Purwandari, Y.

A., Hiryanto, Kusmaryanti, R.E. (2013).

Perkembangan Peserta Didik.

Yogyakarta: UNY Press.

Lesley, M. \& Labbo, L. D. (2003). A pedagogy of control: Worksheets and the special need child.ProQuest, 80,6, 444-452.

Majid, A.\& Rochman, C. (2014). Pendekatan Ilmiah dalam Implementasi Kurikulum 2013. Bandung: PT Remaja Rosdakarya. Mudlofir, A. (2011). Aplikasi Pengembangan Kurikulum Tingkat Satuan Pendidikan dan Bahan Ajar dalam Pendidikan Agama Islam. Jakarta: Rajawali Pers.

Mulyatiningsih, E. (2012). Metode Penelitian Terapan Bidang Pendidikan. Bangdung: Alfa Beta.

Muslich, M. (2011). KTSP Pembelajaran Berbasis Kompetensi dan Kontekstual. Jakarta: Bumi Aksara

Mustofa, M. (2013). Pengembangan Lembar Kerja Peserta didik Berbasis Observasi pada Taman Sekolah Sebagai Sumber Belajar Sains di SD N 1 Tinjomoyo. Skripsi. Dipublikasikan. Universitas Negeri Semarang.

Oren, F. S. \& Ormanci, U. (2012). An Application about Pre-Service Teachers" Development and Use of Worksheets and an Evaluation of their Opinions about the Applicatio.Educational scient:Theory \& practice. 264, 263270.

Prastowo, A. (2013). Pengembangan Bahan Ajar Tematik. Yogyakarta: Diva Press. . (2015). Panduan Kreatif Membuat BAHAN AJAR INOVATIF. 
Yogyakarta: Diva Press.

Sadiman, A. S., Rahadjo, R., Haryono A.,

Rahardjito. (2009). Media

Pendidikan: Pengertian,

Pengembangan danPemanfaatannya.

Jakarta: PT. Raja Grafindo Persada.

Setyosari, P.(2012). Metode Penelitian

Pendidikan dan Pengembangan. Jakarta:

Kencana Pernada Grup.

Sugiyono. (2014). Metode Penelitian

Kuantitatif, Kualitatif, dan $R \& D$.

Bandung: Alfabeta

Sugiyono, Metode Penelitian Dan

Pengembangan (Bandung, Alfabeta, 2017)

Sujarwo. (2011).Model-Model

Pembelajaran suatu Strategi

Mengajar. Yogyakarta: CV Venus Golg Press.

Sun, J. C.-Y., \& Lee, K.-H. (2016). Which Teaching Strategy is Better for Enhancing Anti-Phishing Learning Motivation and Achievement? The Concept Maps on Tablet PCs or Worksheets? Educational Technology \& Society, 19 (4), 87-99.

Sunarto \& Hartono, A. (2013). PERKEMBANGAN PESERTA DIDIK Jakarta: PT. Asdi mahasatya.

Syaifuddin, Pengembangan Lembar Kerja Peserta Didik (LKPD) Berbasis Kontekstual Untuk Meningkatkan Kemampuan Pemecahan Masalah Dan SelfEfficacy Matematis (Tesis Program Studi Magister Pendidikan Matematika, Universitas Lampung,Lampung, 2017)
Taslidere, E. (2013). The Effect of Concept Cartoon Worksheets on Students" Conceptual Understandings of Geometrical Optics. Education and Science Vol. 38, No 167

Trianto . 2009. Mengembangkan Model Pembelajaran Tematik. PT. Prestasi Pustakarya. Jakarta

Widjajanti, Endang. 2008. Kualitas Lembar Kerja Siswa. UNY. Yogyakarta

Widoyoko, E. P. (2010). Evaluasi Program Pembelajaran. Yogyakarta: Pustaka Pelajar.

Yusuf, S. (2007). Psikologi Perkembangan Anak dan Remaja. Bandung : PT. Remaja Rosdakarya.

Yuberti, Penelitian Dan Pengembangan Yang Belum Diminati Dan Perspektifnya Kompilasi Artikel, 2016

Yulianti, Dwi, Inggrit Pratiwi, and Pratiwi Dwijananti, 'Membangun Karakter Siswa Melalui Model Pembelajaran Problem Based Instruction Berbantuan LKS Berpendekatan Scientific Materi Kalor Dan Perubahan Wujud', Unnes Physics Education Journal, 6 (2017) 